Jurnal Administrasi Publik (Public Administration Journal), 10(2) December 2020

ISSN2088-527X (Print) ISSN2548-7787 (Online) DOI: https://doi.org/10.31289/iap.v10i2.3107

Jurnal Administrasi Publik (Public Administration Journal)

\title{
Policy Implementation of Solid Waste Management in South Jakarta
}

\author{
Siti Verawati * \& Retnowati Wahyuning Dyas Tuti ** \\ Muhammadiyah University Jakarta, Cirendeu, Indonesia
}

Received: November 21, 2019; Reviewed: May 05, 2020; Accepted: July 21, 2020

*sverawati08@yahoo.co.id; **retnowatiwdtuti@yahoo.com

\begin{abstract}
Waste management problems are common in big cities in Indonesia, including Jakarta. Various waste problems such as: a significant increase in the volume of waste from year to year, poor waste management, and a low culture of cleanliness in the society still shackles Jakarta nowadays. The policy was initiated in the form of the DKI Jakarta Provincial Regulation No. 3 of 2013 concerning Waste Management to alleviate various solid waste problems, including through the waste bank program and 3R (Reuse, Reduce, Recycle). This study aims at analyzing the implementation of these policies using Edward III theory in Subarsono (2012) which consists of Communication, Resources, Disposition, and Bureaucratic Structure. Qualitative approaches and descriptive methods were used in this research. The results of this study are, the implementation of solid waste management policies in DKI Jakarta Selatan has not been very good. It is due to the socialization of policies and programs carried out by the government only reached the Sub-district level, not yet at the Neighbourhood level; Lack of commitment from the government and the society in supporting the implementation of good waste management. From the bureaucratic structure and authority of the Environmental Agency, it can be stated that it was quite good and met the principles of good governance, less optimal use of budget, with a very large budget (Rp. 3.7 trillion), the problem of flooding and waste accumulation in the river had not been resolved.
\end{abstract}

\section{Keywords: Implementation, Policy, Waste Management}

How to Cite: Verawati, S. \& Tuti, R.W.D. (2020) Implementation of Solid Waste Management Policies in South Jakarta. Jurnal Administrasi Publik (Public Administration Journal). 10(2): 118-126 


\section{INTRODUCTION}

The increasing modern consumption pattern has contributed to various types of waste, one of them is packaging waste, which is dangerous and difficult to break down by natural process. It has a potential negative impact, namely the concentration of waste for both industry, households and transportation activities in urban areas so that it has a serious effect and creates a hazard to the health and life of urban society in Indonesia.

Along with population growth, the urban development and also the demands of the city people, organizations that handle municipal waste must be responsive, adaptive and committed to professional cooperation, which has the characteristics of Transparent, Participatory, Effective and Efficient, and can guarantee public accountability. To develop an institutional model that is suitable for population growth and urban development, it is necessary to conduct a study of municipal waste management institutions, so that the management of municipal waste can be more effective.

In Law No. 32 of 2009 concerning Protection and Management of the Environment. It was explained that the existence of solid waste management in a city aims to serve the waste produced by its society, which indirectly contributes to maintaining public health and creating a clean environment. Currently, solid waste management is experiencing a lot of pressure, especially due to the large amount of waste generated by the society, both producers and consumers.

These problems are common in big cities in Indonesia, including Jakarta. Based on data compiled from the DKI Jakarta Sanitation Office in 2016, the volume of waste in Jakarta is increasing every year. These data are shown inFigure 1.

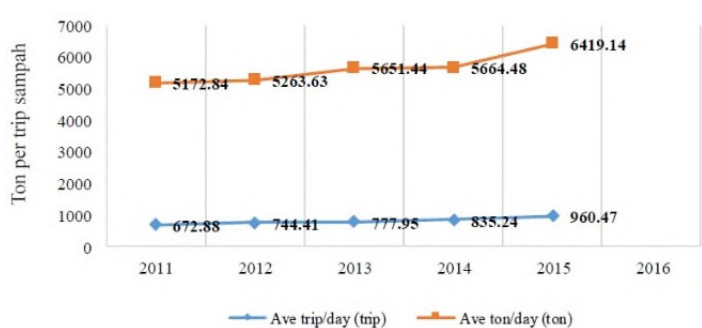

Figure 1. Trends in the volume of waste in DKI Jakarta accommodated by BantarGebang landfill

(Source: DKI Jakarta Sanitation Office, 2016)

This data indicates the trend of increasing waste that occurred from 2011 to 2015 , the culmination was in 2015 with 6,419 tons of DKI Jakarta waste being accommodated at BantarGebang TPA. The majority was waste that has weathered or organic. In a day, the average TPST BantarGebang received 6,802 tons of waste from Jakarta. The average residential area of DKI residents produced 3,4004 liters of garbage per day.

This waste was still dominated by organic waste with a percentage of 53.75 percent, plastic waste 14.02 percent, mixed waste 11.94 percent, glass waste 2.45 percent, metal waste 1.82 percent and textile waste 1.11 percent. The largest source of waste in DKI Jakarta comes from settlements, reaching 60.5 percent. Then office waste 22.5 percent. Industrial waste, hotels, shops, 3.4 percent, school waste 0.2 percent, market waste 2.8 percent, and others such as from roads, terminals, parks 10.6 percent.

The very large volume of municipal waste indicates that waste management in DKI Jakarta has been already at an alarming stage if it is not managed properly, where the potential for conflict can explode at any time. Therefore, it is necessary to do a comprehensive rearrangement of the concept of urban solid waste management including TPA waste management. The problems that are urgent and difficult to solve for people in big cities are the distribution chain that is too long and the centralized TPA pattern. The concept of a waste management plan needs to be made with the aim of developing a waste 
management system that is modern, reliable and efficient with environmentally friendly technology (Dasuki, 2008).

The waste problem is getting more complex along with the increasing population, the heterogeneity of the socioeconomic and cultural conditions of the people in the city, the lack of seriousness of the government and society in managing and dealing with waste problems, and the incompatibility of the concept of waste management applied to a certain area. Most of the waste management in DKI Jakarta is not managed sustainably, it is asBantargebang landfill (TPA) in Bekasi as DKI Jakarta waste is still in a poor condition and garbage piles up openly (open dumping).

An open garbage disposal system is no longer permitted as mandated by Law Number 18 of 2008 concerning Solid Waste Article 29 letter (e) which reads: "It is prohibited to handle waste by open disposal at the final processing site". The prohibition of open piling up waste in the TPA, considering that the stacked garbage is left open and let the leachate not managed, as well as methane gas (CH4) which occurs due to biochemical reactions, explosions and fires often occur in the landfill. Like BantarGebang TPA, this type of TPA is very damaging to the environment and is a source of various diseases, polluting the air, soil and groundwater, polluting irrigation and waterworks, disturbing odors up to a radius of 5-10 km, destroying aesthetics, causing flooding and crises, clean water and potential social conflicts.

The enactment of Law Number 18 of 2008 concerning Waste Management and Government Regulation Number 81 of 2012 concerning Management of Household Waste and Waste Similar to Household Waste encourages policy direction as well as waste reduction and handling programs which include targets for reducing waste generation and prioritizing types of waste gradually, as well as the target for waste handling for any given period of time.

The problem of waste in Jakarta is so complex, even after 5 years since the enactment of Law Number 18 of 2008, the DKI Jakarta government has just issued the Provincial Regulation of the Special Capital Region of Jakarta Number 3 of 2013 concerning Waste Management. This policy was issued in the context of implementing a waste management program. Based on the descriptions of waste management problems as described above, this study seeks to answer the research question "How is the implementation of solid waste management in South Jakarta?".

The first research by WillianDjani, Jacob Wadu, Primus Lake "Policy of Solid Waste Management Based on Society Participation in the Department of Cleanliness and Environment in Kupang. This paper is intended to provide answers of some society participation-based waste management policy efforts at Kupang Cleanliness and Environment Agency in realizing a clean and healthy Kupang. Waste management policies that involve the society and other elements are important in producing quality waste policies so that the actors can understand and carry out their roles optimally, which is the result of the convergence of external and internal factors in supporting change (Djani \& Wadu, 2019).

The second research by Maulidyka Agustyan Sudrajat, Daud Liando, Stefanus Sampe, "Implementation of Waste Management Policy and Cleaning Service Retribution in Manado City". The results showed that in implementing waste management policies and cleaning service fees, Manado government had carried out its obligations, it indicates that there was strong support and a great desire to implement policies according to what the initial decision was. However, the public awareness of disposing of garbage in its place and hours of throwing garbage was still less. (Sudrajat \& Liando, 2017).

The third research by Andi Cahyadi, Sraiti Sriati, Andy Al-Fatih "Implementation of Waste 
Management Policy through a Waste Bank in Purbalingga Regency". The findings indicates that the implementation of waste management policies through waste banks in Purbalingga district according to the level of compliance, smooth functioning, performance and impact of the waste bank, still has not shown the optimal results yet so that it cannot be considered successful. Therefore it is necessary to improve support from all parties, and policy makers from Purbalingga district(Cahyadi \& Sriati, 2019).

The fourth research on the implementation of environmental management policies at the Provincial Government of North Sumatra was seen from the following factors: policy communication, resources used in policy implementation such as human resources and funding sources as well as infrastructure, trend factors and bureaucratic structure factors, indicates that in the process the implementation of environmental management policies in North Sumatra had not been effective. When viewed from each indicator, it showed that from the four indicators only communication indicators were classified as effective, while for indicators of trend and bureaucratic structure, such as human resource and funding sources, infrastructure had not been effective.

The ineffective implementation of Environmental Management policies in the Provincial Government of North Sumatra, due to lack of financial support, lack of coordination between the central and regional governments, the quality of human resources implementing policies was still low, frequent changes in organizational structures and policies, and policy makers and implementers were in different agencies(Marsuyetno \& Harahap, 2014).

The fifth research. The Waste Bank is a national movement for environmental hygiene and health. The concept of a waste bank has begun to be widely practiced in Indonesia, where people can carry certain waste, which then can be processed into useful materials. One of them is the Mutiara Medan Waste Bank, through the waste bank we save waste and get money. In addition, to provide economic benefits, it is certain that the existence of a Waste Bank will provide benefits for environmental cleanliness. This research was a descriptive study with a qualitative approach using indepth interviews to find out how the implementation of Medan Mayor Regulation No. 14 of 2014 concerning the Garbage Bank in Mutiara Waste Bank of Binjai Village, Medan Denai District, Medan City in 2016. The results indicaes that the Mutiara Waste Bank had a role in the society's economy to get additional income, in terms of social society as a center for environmental-based society activities, in terms of environmental cleanliness to be able to create a clean, healthy, and comfortable environment. The obstacles in the operation of Mutiara Waste Bank were the lack of active participation from the society, the lack of means of transportation for transporting waste, the lack of access to marketing of recycled waste products, and the lack of support from the government (Dongoran, Harahap \& Tarigan, 2018).

\section{RESEARCH METHOD}

The research method used was a qualitative approach with descriptive method. A qualitative approach provides flexibility to view social phenomena holistically. Meanwhile, the descriptive method focuses on the meaning (events, processes, and themes) in depth, which are then described in the form of words and pictures. A qualitative approach with a descriptive method was chosen because this study intended to describe in detail and interpret the data obtained, and to explain the dynamics of solid waste management policy implementation in South Jakarta.(Creswell, 2014).

The data used in this study came from various primary data obtained from indepth interviews and Focus Group Discussions (FGD) with the Head of 
Division 3 of the South Jakarta Environmental Office, 2 Officers of 3R at South Jakarta Environmental Office, 2 Garbage Bank Officers, and 5 People of South Jakarta. The data were then analyzed using Edward III theory in (Edwards, 1980) about the implementation of policies which consist of 4 measurement dimensions, namely: communication, resources, disposition, and bureaucratic structure.

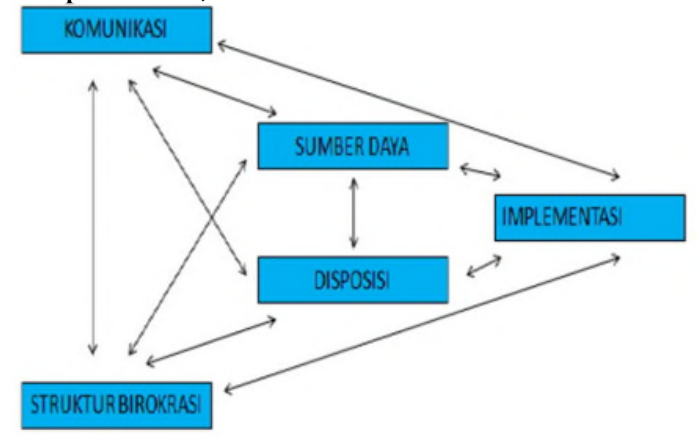

In this study, the theory used as a weapon of analysis is the theory of Edward III in Subarsono (2012). The consideration of choosing this theory was based on the suitability of the variables in the theory with the various problems existed in the implementation of solid waste management policies in South Jakarta.

\section{RESULTS AND DISCUSSION}

Based on Edward III, the implementation of policy is influenced by 4 (four) variables, namely:

\section{Communication}

The successful implementation of policies requires the implementers know what to do. What are the goals and objectives of the policy must be transmitted to the target group so that it will reduce distortions in implementation. If the goals and objectives of a policy are not clear or even completely unknown to the target group, then there is likely to be resistance from the target group.Communication is one of the important aspects in the success of implementing a policy. Good communication between organizations implementing policies will facilitate the policy diffusion process, on the other hand, bad communication can hinder policy implementation.

Based on the results of interviews with the Head of Division 3 of the South Jakarta Environmental Office, it was found that to solve the waste problem in South Jakarta was carried out through the waste bank program and the 3 $\mathrm{R}$ (Reduce, Reuse, Recycle). That is how he statedas follows:

"I think all parts of Jakarta, not only South Jakarta, have a waste bank program that is spread across many urban villages. Apart from that, there was also a 3R program (Reduce, Reuse, Recycle) to optimize the existing waste so that it had economic value so that it gave benefits the society.

This statement was reinforced by the 3R Officer at the South Jakarta Environment Office who stated that:

"We have a program to solve the complex waste problem in DKI, namely through the waste bank and $3 \mathrm{R}$ ".

These programs sought to be communicated to the society through socialization to sub-districts, schools, and PKK (Program of Family Welfare) women. As stated by the $3 \mathrm{R}$ officers and Mampang District garbage bank officer as follows:

"We usually do socialization in the urban villages to inform about the waste bank and the benefits that will be obtained from the existence of a waste bank, and we also conduct socialization at schools".

"Usually we go through the district or PKK women to socialize to the society, as well as trainings for handicrafts from waste".

However, when it was confirmed to the residents of South Jakarta regarding their knowledge of two programs and whether there were any socialization by the local government to the society, the following answers were obtained:

"There is no official socialization, counseling and information provision from the head of Neighbourhood, only the people' own initiative to recycle their waste, such as plastics, bottles and others".

This opinion was strengthened by the statements of other people who claimed not to 
know the 3R program of South Jakarta city government who stated:

"What program? I didn't know there was a program for creating waste here".

Based on the results of interviews with the government and the society as described above, it can be justified that the communication variables in the implementation of solid waste management policies in South Jakarta had not been very good. It was as the communication run by the government only reached the Sub-District level, not yet at the Neighbourhood level. This justification was illustrated by the people who did not know about the waste bank program and 3R. In addition, they were also not aware of any socialization carried out by the South Jakarta government.

It is unfortunate because based on Edward III, the success of policy implementation requires good communication, thereby reducing distortions in implementation. If the goals and objectives of a policy were not clear or even completely unknown to the target group, then there is likely to be resistance from the target group.

\section{Resources}

Even though the content of the policy has been communicated clearly and consistently, if the implementor lacks the resources to implement it, the implementation will not be effective. These resources can be in the form of human resources, infrastructure, and financial resources. Resources are the important factor for effective policy implementation. Without resources, the policies only stay on paper, become documents.

From the aspect of human resources, the main implementor of the waste bank program and the 3Rs was the Officer for Handling Public Infrastructure and Facilities (PPSU). In terms of numbers, it can be states as sufficient since in South Jakarta there are 440 PPSU officers. It was as stated in the interview with the Head of Division 3 of the South Jakarta Environmental Office as follows:

"We have around 440 PPSU officers to support the implementation of waste management policies in all parts of Jakarta, not only South Jakarta, which has a waste bank program that is spread across many urban villages. Apart from that, there is also a $3 \mathrm{R}$ (Reduce, Reuse, Recycle) program to optimize the existing waste so that it has economic value so that it gives benefits to the society.

Apart from the adequate quantity of human resources, supporting facilities and infrastructure are also needed. It is important to ensure the smooth running of the policies that have been set. In this regard, the 3R Officer at the South Jakarta Environmental Office stated that:

"We certainly facilitate everything, from garbage trucks, even garbage trucks that are specifically for inorganic, and for the garbage banks that would like to transport waste to the main waste bank, we provide facilities for transporting it,even we also provide a saving book".

On the other hand, in terms of financial resources The DKI Jakarta Provincial Government was benefited from the large amount of budget provided for waste management. In fact, it can be stated that the amount is quite fantastic, namely Rp. 3.7 trillion. As explained by the Head of Division 3 of the South Jakarta Environment Office:

" DKI Jakarta Provincial Government does have a large enough budget allocated to solve the existing solid waste problem. We have a budget of Rp. 3.7 trillion. It will then be divided proportionally into 5 areas of Jakarta, including South, North, West, East and Central".

Based on the results of in-depth interviews with these informants, it can be analyzed that the resource variable is sufficient both in terms of the quantity of human resources, facilities and infrastructure. From a budget point of view it is also very large, namely Rp. 3.7 trillion, the amount is far above the budget for solid waste in Surabaya, which is only Rp. 30 billion.

\section{Disposition}

Disposition is the character and characteristics possessed such as commitment, honesty, and democratic character. If the 
implementor has a good disposition, then he will be able to carry out policies properly as desired by policy makers. When the implementor has a different attitude or perspective from the policy makers, the policy implementation process will also be ineffective.

In this regard, the Head of Division 3 of the South Jakarta Environmental Office stated that his party is committed to collecting the waste through a garbage truck that is available every 3 times a week. It was as quoted from the following interview:

"Of course we are committed to carrying out waste management in South Jakarta. Every three times a week the garbage trucks that we have always pick up the waste from garbage dumps in South Jakarta. The people should have sorted the waste so that it is easy for our officers to separate wet and dry waste, organic and non-organic waste. But the reality is that there were still many of our people who do not understand this, so they tend to be careless in disposing of waste".

The statement of the Head of the Division was strengthened by the arguments of the Garbage Bank Officer in South Jakarta who also complained about the low awareness of society to do waste sorting. In fact, it is an important thing if this waste management is successful. The following is an excerpt from the interview:

"Often, in carrying out our duties, we find the fact that our society has very low awareness. Even though we have been quite intense in informing and emphasizing the importance of sorting waste. However, there are people, even in large numbers, who still mix all the existing waste and throw it away without sorting it out first. It is of course makes it difficult for us as garbage officers. It's not good if it isgoingon".

After being validated with the society, they admit that they do not sort the waste that is to be disposed of. However, they argued that they did not know well about the waste separation rules and the technical implementation because they did not get complete information from the government. It was as expressed by one of the people who became the following informants:
"Yes, I have never done sorting waste. But the government has also never provided concrete information on this matter. I didn't know that the trash we wanted to dispose of had to be separated first. Never got this info before".

The second informant from another society also said the same thing. It is reflected in the following statement:

"I don't know Mam that if we want to dispose of trash, we should separate which one is wet or not, which is organic or not. The problem is we were not told beforehand. I also want to complain, our government is not disciplined. What I know is that the garbage pickers should come three times a week. But what happened was they came only twice a week. Sometimes it was just once a week, waited for the trash can become so full that it creates an uncomfortable smell".

Based on the explicit explanation from the informants above, it can be stated that the commitment of both parties (both government and society) were equally lacking in supporting the implementation of good waste management in South Jakarta City. The government complained about the fact that many people did not sort the waste before it was disposed of, making it difficult for officers who wanted to manage waste and make the $3 \mathrm{R}$ program effective.

On the other hand, the society also complained about officers who did not provide concrete information regarding the rules and the society's obligation to sort waste before disposal. Apart from that, another thing that has become a complaint was the garbage pickup officers were not committed to carrying out their duties because they only came twice, even once a week to pick up trash, which often created a smell that disturbs the society. In fact, as stated by the garbage bank officer himself, the garbage carrying officer / truck should come three times a week to carry the people' garbage.

\section{Bureaucratic Structure}

The organizational structure which implementing the policies has a significant 
influence on policy implementation. One of the important structural aspects of any organization is the existence of standard operating procedures (Standard Operating Procedures on SOP). SOPs serve as guidelines for every implementor in action.

Based on the Regulation of the Governor of DKI Jakarta Province Number 131 of 2009 dated August 4, 2009 concerning the Organization and Work Procedure of the Environmental Agency, the Environmental Agency is the SKPD that is mandated to solve the waste problems in DKI Jakarta. The organizational structure of the Environmental Agency and job descriptions of the fields contained in the Environmental Service are as follows:

1. Head of the Environmental Agency

2. Deputy Head of the Environment Agency

3. Secretariat of the Department of Environment. The Secretariat is a Work Unit for the Environmental Service staff led by a Service Secretary and is under the Head of the Service and is responsible to the Head of the Service. The secretariat carried out administrative duties of the Sanitation Service. The Office Secretary is in charge of 4 Sub Division Heads:
a. General subsection
b. Sub Division of Personnel
c. Sub-section Program and Budget
d. Sub Division of Finance

4. Hygiene Management Engineering Sector

5. Sector of Handling and Control of Cleanliness

6. Infrastructure and Facilities

7. Sector of Society Participation Development and Cleaning Business

8. Integrated Waste Management Unit

As a technical implementing element within the DKI Jakarta Provincial Government, the Environmental Agency has the main task of carrying out hygiene management for the creation of a clean, orderly, beautiful and healthy city of Jakarta. In carrying out these tasks, the Environmental Office has the following functions:
1. Preparation and implementation of the Work Plan and Budget (RKA) of the Environmental Office.

2. Formulation of technical policies for the implementation of hygiene management.

3. Solid waste management and septic tank wastewater.

4. Provision of infrastructure and facilities of cleanliness countermeasures.

5. Guidance and development of society participation in efforts to improve environmental and residential cleanliness.

6. Development of solid waste management and septic tank waste water.

7. Service, guidance and control of recommendations, standardization and / or licensing in the part of hygiene

8. Enforcement of laws and regulations in the part of hygiene

9. Collection, administration, deposit, reporting and accountability for receiving cleaning fees

10. Provision, administration, use, maintenance and maintenance of hygiene infrastructure and facilities

11. Providing technical support to the society and regional apparatus

12. Management of personnel, finances, goods, and administration of the Sanitation Office

13. Reporting and accountability for the implementation of duties and functions.

The Environmental Service SubDepartment is an element implementing regional autonomy in part of cleanliness. The Environmental Service Sub-Department is led by a Head of the Sub-Office under the Governor and is responsible to the Governor through the Regional Secretary. In carrying out his duties, the Head of the Environmental Office is assisted by a Deputy Head of the Sub-Department.

In supporting its main duties and functions, the Environmental Agency can also recruit people who are employed as officers for the handling of public infrastructure and facilities (PPSU). From the bureaucratic structure and authority of the Environmental Office, it can be stated that it was quite good and met the principles of good governance. 


\section{CONCLUSION}

The implementation of waste management policies in South Jakarta had not been very good, this is due to the fact that several obstacles were still found in implementing waste management. Weak communication from the DKI Jakarta government to the public.It is due to the socialization of policies and programs carried out by the government had only reached the Sub-district level, not yet at the Neighbourhood level; Lack of commitment of both parties (both government and society) in supporting the implementation of good waste management in South Jakarta. From the bureaucratic structure and authority of the Environmental Office, it can be stated that it was quite good and met the principles of good governance. It was reflected in the government who complained about the fact that many people did not sort the waste before it was dumped. On the other hand, the people also complained about the officers who did not provide concrete information about the rules and the society's obligation to sort waste before disposal. Another complaint was the garbage pick-up officers who were not committed to carrying out their duties because they only came twice, even once a week from the supposed schedule, namely three times a week to pick up trash; Less optimal use of the budget. It is due to with a very large budget (Rp. 3.7 trillion) to process waste in DKI Jakarta, the problem of flooding and waste accumulation in the rivers had not been resolved.

\section{BIBLIOGRAPHY}

Cahyadi, A., \& Sriati, A.A.F. (2019). Implementasi Kebijakan Pengelolaan Sampah Melalui Bank Sampah Di Kabupaten Purbalingga. Demography Journal of Sriwijaya, 2(1): 9-16.
Creswell, J. W. (2014). Research Design: Qualitative, quantitative and mixed methods approaches. Https://doi.org/10.1007/s13398-014-01737.2antitative,. Research Design Qualitative Quantitative and Mixed Methods Approaches. https://doi.org/10.1007/s13398-014-01737.2

Dasuki, A. (2008). StrategiPengelolaan TPA Bantargebang. UniversitasMuhammadiyah Jakarta.

Djani, W., \& Wadu, J. (2019). Kebijakan Pengelolaan Sampah Berbasis Partisipasi Masyarakat Di Dinas Kebersihan Dan Lingkungan Hidup Kota Kupang. Journal of Business Studies, 4 (2): 9- 18.

Dongoran, H.S. Harahap, R.H., Tarigan, U., (2018). Implementasi Peraturan Walikota Medan tentang Unit Pelaksanaan Teknis Pelayanan Kebersihan dan Bank Sampah. Jurnal Administrasi Publik (Public Administration Journal), 8(1): 47-64.

Edwards, G. C. (1980). Implementing Public Policy. Congressional Quarterly Inc.

Marsuyetno. \& Harahap, R.H.. (2014). Analisis Implementasi Kebijakan Pengelolaan Lingkungan Hidup Di Sumatera Utara (Studi Pada Badan Lingkungan Hidup Provinsi Sumatera Utara). Jurnal Administrasi Publik (Public Administration Journal), 2(1): 85-107.

Maulidyka Agustyan Sudrajat, Daud Liando, S. S. (2017). Implementasi Kebijakan Pengelolaan Sampah dan Retribusi Pelayanan Kebershan di Kota Manado. Jurnal eksekutif, 1(1): 12-20

Subarsono, A.G. (2012). Analisis Kebijakan Publik (Konsep, teori, dan Aplikasi). Yogyakarta: Pustaka Pelajar.

Regulations

Law Number 18 of 2008 concerning Waste Management.

Number 81 of 2012 concerning Household Waste Processing.

Law No. 32 of 2009 concerning Protection and Environmental Management.

Regulation of the Governor of DKI Jakarta Province Number 131 of 2009 dated August 4, 2009 concerning the Organization and Administration of the Environmental Agency

Provincial Regulation of the Special Capital Region of Jakarta Number 3 of 2013 concerning Waste Management. 